\title{
Architecture_MPS
}

\section{Hazing Iran: Satellite Imagery, Human Rights, and City as Camp}

Amy Zhang ${ }^{1}$

How to cite: Zhang, A. 'Hazing Iran: Satellite Imagery, Human Rights, and City as Camp.' Architecture_MPS, 2014, 5(1): 2, pp. 1-15. DOI:

https://doi.org/10.14324/111.444.amps.2014v5i2.001.

Published: 01 June 2014

\section{Peer Review:}

This article has been peer reviewed through the journal's standard Editorial double blind peer review.

\section{Copyright:}

(C) 2014, The Author(s). This is an Open Access article distributed under the terms of the Creative Commons Attribution License (CC-BY) 2.0 https://creativecommons.org/licenses/by/2.0/, which permits re-use, distribution and reproduction in any medium, provided the original author and source are credited • DOI: https://doi.org/10.14324/111.444.amps.2014v5i2.001

\section{Open Access:}

Architecture_MPS is a peer-reviewed open access journal. 


\section{Title: Hazing Iran: Satellite Imagery, Human Rights, and City as Camp}

Author: Amy Zhang

Architecture_media_politics_society. vol.5, 1no.2.

June 2014

Affiliation: Columbia University, New York

Abstract:
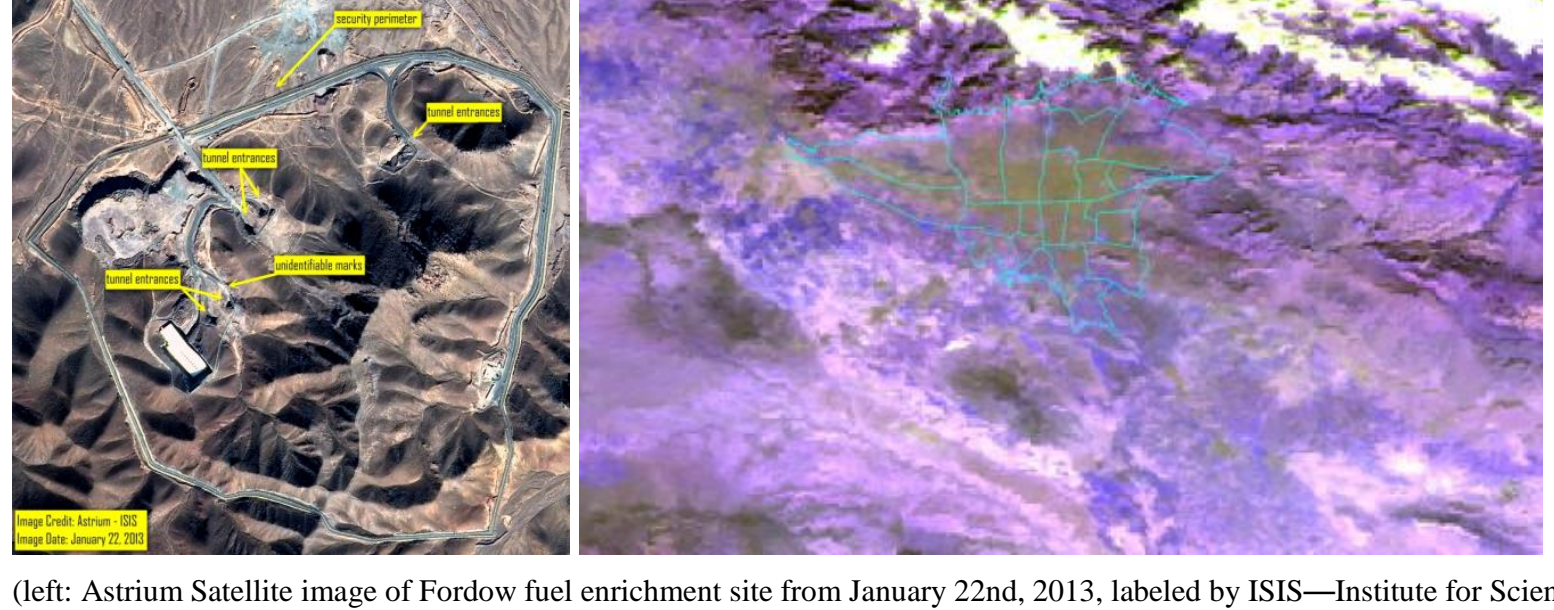

(left: Astrium Satellite image of Fordow fuel enrichment site from January 22nd, 2013, labeled by ISIS-Institute for Science and International Security)

(right: MODIS Satellite image of Tehran smog, edited in Iranian scientific study "Application of satellite data and GIS in studying air pollutants in Tehran")

As perhaps most obviously evidenced in the political maneuverings that led up to the second Gulf War in 2003, the use of satellite imagery to document spatial terrain is often, and almost instantly, politicized. In the two images presented here, this politicization takes on a two-way relationship and is open to contrasting and inevitably dualistic readings. One way of describing their relationship is as "Target" and "Aftermath". On the left, we have an image of the nuclear plant near the Iranian city of Qom, annotated in this version by the US security services to highlight 'suspicious' activity said to evidence the nuclear ambitions of the Iranian government. On the right, we are presented with an image of Tehran under heavy smog in 2013 released by the Iranian government itself. Although the official Iranian explanation for this smog is the general population density and industrialization of the city, it has now been acknowledged, or is at least extensively argued, that the pollution it documents is a direct result of the economic sanctions imposed by the United States in 2010 that banned the sale of refined fuel to the country. Facing a major 


\section{Amps}

energy crisis that would completely stall the economy, the Iranian government opted to produce a "bathtub mix" of far inferior quality oil that has been releasing deadly exhaust into the already dense air of Iran for the past three years.

The "Target", as the first image shows, is Iran's nuclear program, which lies at the crux of complicated historical animosities currently evident between the US and Iranian governments. Taken at very high resolution (2.5 meters per pixel) from outer space, the image presents itself as tunnel-vision precision each point is a piece of data and each piece of data details coordinates, date, and time. It is on the back of such supposed satellite precision that the crippling economic sanctions of the US's policy of containment are justified. However, the aftermath of these sanctions has not been the cessation of Iran's nuclear program, but rather the suffocation of Tehran. Indeed, it has been argued that the inhabitants of Tehran are almost literally "choking to death". By the standards of the sanctions' purported aims, the result seems more an egregious misfire than a successful piece of foreign policy.

The reality behind these images and their conflicting ascribed narratives is far from clear. The effects on the people of Iran are also not only equally unclear, they are deliberately hazed. Employing Giorgio Agamben's notions of the abstraction of the citizen to 'bare life' and its corollary of the 'Camp' as the 'Nomos' of the Modern, this paper attempts to decipher these images, their politicized readings, and the way in which the sites of human life in and near their locations - the occupants of the city of Qom in the first instance and those of Tehran in the second - have been conspicuously erased. It will argue that this visual erasure from spatial representation has fundamental implications for the human rights of the inhabitants of these cities and, by extension, Iran and a politicized world more generally. In doing so, it will suggest that as spaces and places of political conflict are ever more frequently presented through the medium of the satellite image, a deeply politicized reading of their structures, narratives and spatial representative techniques becomes ever more important. 


\title{
Title: Hazing Iran: Satellite Imagery, Human Rights, and City as Camp
}

\author{
Authors: Amy Zhang
}

Architecture_media_politics_society. vol.5, no.2.

June 2014
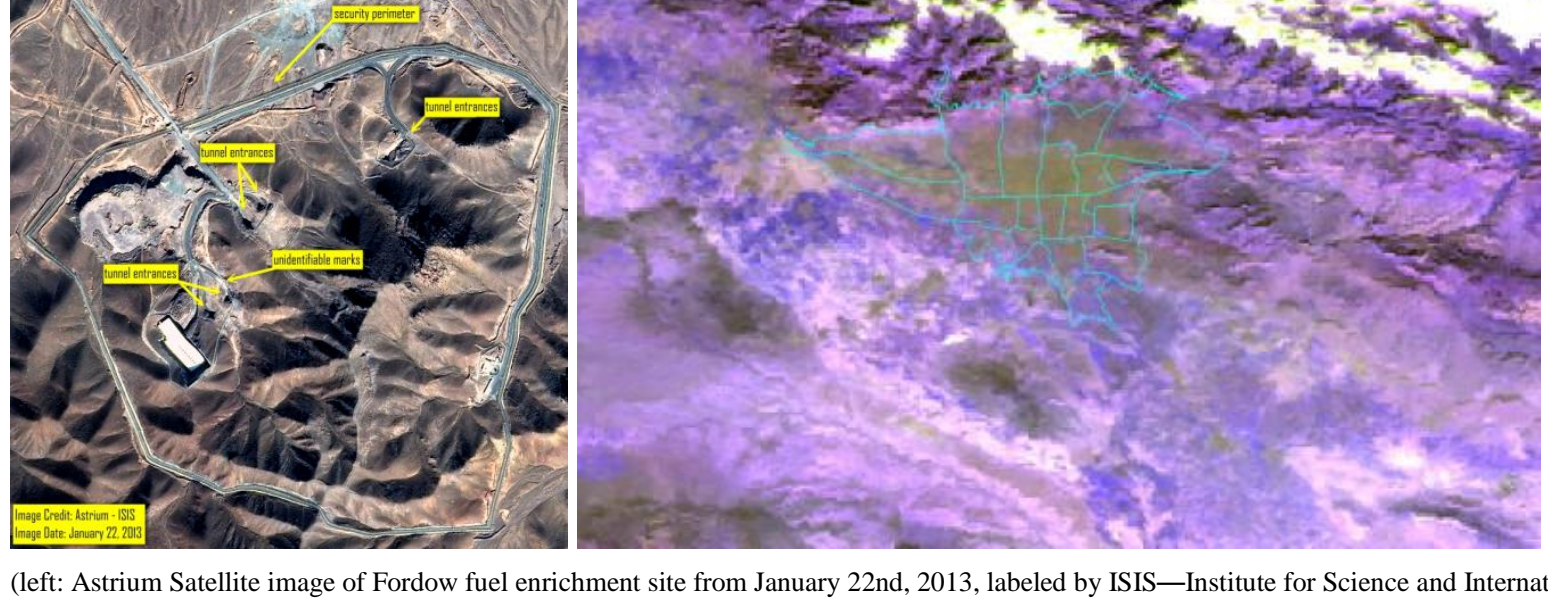

(left: Astrium Satellite image of Fordow fuel enrichment site from January 22nd, 2013, labeled by ISIS-Institute for Science and International Security)

(right: MODIS Satellite image of Tehran smog, edited in Iranian scientific study "Application of satellite data and GIS in studying air pollutants in Tehran")

\section{INTRODUCTION}

As perhaps most obviously evidenced in the political maneuverings that led up to the second Gulf War in 2003, the use of satellite imagery to document spatial terrain is often, and almost instantly, politicized. In the two images presented here, this politicization takes on a two-way relationship and is open to contrasting and inevitably dualistic readings. One way of describing their relationship is as "Target" and "Aftermath". On the left, we have an image of the nuclear plant near the Iranian city of Qom, annotated in this version by the US security services to highlight 'suspicious' activity said to evidence the nuclear ambitions of the Iranian government. On the right, we are presented with an image of Tehran under heavy smog in 2013 released by the Iranian government itself. Although the official Iranian explanation for this smog is the general population density and industrialization of the city, it has now been acknowledged, or 
is at least extensively argued, that the pollution it documents is a direct result of the economic sanctions imposed by the United States in 2010 that banned the sale of refined fuel to the country. ${ }^{1}$ Facing a major energy crisis that would completely stall the economy, the Iranian government opted to produce a "bathtub mix" of far inferior quality oil that has been releasing deadly exhaust into the already dense air of Iran for the past three years. ${ }^{2}$

The "Target", as the first image shows, is Iran's nuclear program, which lies at the crux of complicated historical animosities currently evident between the US and Iranian governments. Taken at very high resolution (2.5 meters per pixel) from outer space, the image presents itself as tunnel-vision precision each point is a piece of data and each piece of data details coordinates, date, and time. It is on the back of such supposed satellite precision that the crippling economic sanctions of the US's policy of containment are justified. However, the aftermath of these sanctions has not been the cessation of Iran's nuclear program, but rather the suffocation of Tehran. Indeed, it has been argued that the inhabitants of Tehran are almost literally "choking to death". ${ }^{3}$ By the standards of the sanctions' purported aims, the result seems more an egregious misfire than a successful piece of foreign policy.

The reality behind these images and their conflicting ascribed narratives is far from clear. The effects on the people of Iran are also not only equally unclear, they are deliberately hazed. Employing Giorgio Agamben's notions of the abstraction of the citizen to 'bare life' and its corollary of the 'Camp' as the 'Nomos' of the Modern, this paper attempts to decipher these images, their politicized readings, and the way in which the sites of human life in and near their locations - the occupants of the city of Qom in the first instance and those of Tehran in the second - have been conspicuously erased. It will argue that this visual erasure from spatial representation has fundamental implications for the human rights of the inhabitants of these cities and, by extension, Iran and a politicized world more generally. In doing so, it will suggest that as spaces and places of political conflict are ever more frequently presented through the medium of the satellite image, a deeply politicized reading of their structures, narratives and spatial representative techniques becomes ever more important.

The link between the two photos presented here can be explained, on one level at least, as a straightforward before-and-after relationship. However, the glaring paradox between the satellite's technological precision in the first image, and the ensuing chaos of smog seen in the second, points to much more than simple antagonistic relations manifested sequentially in these satellite representations of space. Firstly, both satellite images simultaneously mediate the city of Tehran - mediation here being understood as a particular attempt at a given narrative construction amidst a context of disagreement and conflict and aiming for resolution. Secondly, whilst operating in different registers and through different actors, together they illuminate something essential to understanding satellite technology as a mediatory device: that satellite technology is more than a technique of revealing or proving - it is a technique of building. They do so by opening themselves to two quite different readings of the "truth", neither of which foreground the human actors impacted by their narratives.

In concealing or erasing the human actors impacted by the political narratives ascribed to these images, these satellite representations reveal the possibility of nefarious dimensions of this technique of building. What is being built by the satellite (through its imagery) here, is a spatial typology increasingly prevalent 


\section{Amps}

in today's world: that of camp, vis-à-vis Georgio Agamben. For Agamben, this construction of space and spatial representation devoid of actors is a strategy wherein the state responds to threats to its sovereignty by re-asserting direct control of bodies through the abstraction of the citizen to 'bare life'- their reduction to an object without presence and thus, without rights. Such moves - visual, rhetorical and finally, tangibly political — are central to the rationale behind these, and other similar, satellite images.

\section{POLITICAL BACKGROUND}

Iran's nuclear program has been the central point of contention between the US and Iran throughout what is now their thirty-five year old conflict. Iran's nuclear energy program was initially created with the full support and backing of the US in 1957, under the auspices of Eisenhower's Atoms for Peace program. This program's pronounced intention was "to help solve the fearful atomic dilemma" that had manifested its destructive capacities in Hiroshima and Nagasaki. It was, from the outset, part and parcel of US Cold War strategy. In this context, Iran, which shared two thousand miles of border with the USSR, was a natural strategic investment. ${ }^{5}$ All partnerships and deals revolving around this policy, however, were abruptly dropped when popular demonstrations against Shah Mohammad Reza Pahlavi's regime led to the monarchy's deposition in 1979. Shah Mohammad Reza Pahlavi had been a favorite among Western powers for over twenty years and had been installed on his throne by a CIA-backed coup in $1953^{6}$. Ruhollah Mostafavi Musavi Khomeini, a religious scholar, became the Supreme Leader of the new Islamic Republic's democratic-theocratic hybrid government. The nuclear program came to a standstill through both the retraction of international support coupled with the Ayatollah's decision to desist activities, believing nuclear power to be contrary to the ethics of Islam. ${ }^{7}$

The narrative propagated by those on the extreme right in both the US and Israel potentially explains Iran's resumption of its nuclear program as driven by sheer animosity towards Israel and America and, ultimately, the aim of Israel's total destruction. Israeli Prime Minister Benjamin Netanyahu has often employed a "rhetoric about a nuclear-armed Iran constituting an 'existential threat' to Israel" — a conviction then implicitly encouraged by statements like that of US President Obama declaring that "Israel, a small country of less than eight million people, looks out at a world where leaders of much larger nations threaten to wipe it off of the map." However, there are a number of other reasons one might speculate on to explain the renewal of this program that began in $1984 .{ }^{10}$ One reason might in fact be Iran's own feelings of being 'under threat'. The regime of Ayatollah Khomeini restarted the nuclear program during the Iran-Iraq war (1980-1988), an eight-year military conflict that began when Iraq, under Saddam Hussein, invaded Iran. Allegedly, this was Iraq's attempt to lay claim to the disputed waterway, the Shat al-Arab, which forms the boundary between the two countries; however, it is arguable that the larger motivation was to overthrow the Ayatollah Khomeini regime, as Saddam was feeling his own authoritarian power threatened by the model of the Islamic revolution. ${ }^{11}$ During this time, not only did the West fail to condemn the invasion, they sided with Iraq and even blamed Iran for the war. ${ }^{12}$ This example of bellicose realpolitik was followed by the US military victory in the First Gulf War (1991), the subsequent invasion of Afghanistan, and occupation of Iraq in 2003. Each of these major political moves by the US in the region have, arguably, served to exacerbate the Islamic regime's sense of vulnerability: indeed, if it were in fact the Iranian government's intention to develop a nuclear capability (or to be in the 
position of "nuclear ambiguity" that Israel occupies), it would be reasonable to argue, as Adam Tarock has, that it would be a capability premised "not on launching missiles against its foes, but on strengthening its political and diplomatic hand across west Asia."13.

Furthermore, it is arguable that the push for nuclear energy in Iran is one based purely on domestic energy consumption needs. Iran possesses the fourth largest oil reserves and the second largest natural gas reserves in the world (amounting to $15.3 \%$ of the world's total gas reserves); however, since the revolution, the population of the country has more than doubled to seventy million, while oil production has fallen to about seventy percent of pre-revolution levels. ${ }^{14}$ In addition, the country finds itself in a situation in which large amounts of reserves are earmarked for export so as to bring in the revenue necessary to pay for the country's economic development. When one adds to this Iran's historically precarious relationship with the international community that has seen it excluded from various multimillion dollar energy transactions and 'double crossed' in contract negotiations, Iran's argument for developing nuclear energy as an alternative source of fuel for reasons of financial and energy sufficiency can be seen as both credible and sensible.

\section{SATELLITE IMAGE 1: NUCLEAR PLANT, FORDOW, IRAN}

The rejection of the possibility of non-bellicose Iranian intentions in its development of a nuclear energy program clearly lie at the heart of the current stand-off between Iran and the US, and it is not surprising that in this complex context, negotiations around it have remained, until recently, largely at an impasse. Actions and moves by both sides can be said to be overdetermined by what Eva Horn has described as "the epistemology of enmity"15, where truth and its actual pursuit become ancillary, even inconsequential. In this condition, opposing claims for truth are fiercely defended as facts and nowhere is this more visible than in the arguments surrounding the 'truth' behind satellite imagery of Iran's primary nuclear processing plant at Fordow. Regarding the satellite image specifically, Horn writes, "the space of intelligence becomes smooth, homogeneous, and dreamily transparent. From above - and higher up the better - nothing can be hidden; it is the wish for absolute clarity fulfilled." ${ }^{\text {"16 }}$ Yet the photographic artifact of the satellite image is inevitably misconstrued by the tautology of epistemic enmity wherein the image "is created, circulated, and eventually discarded in an imaginary space that quite possibly is nothing more than one's own interior, but which is experienced as 'external.",17 The epistemology of enmity, and its mobilization of the satellite's unstable dialectic between evidence and obfuscation, comprise the starting point for ascertaining the mediation of Tehran by the image of Fordow's nuclear plant (Figure 1). 


\section{Amps}

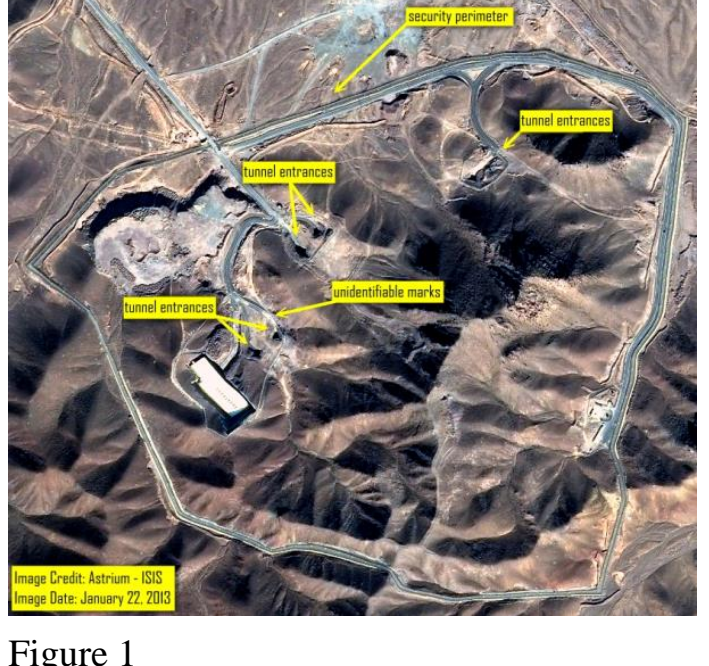

Figure 1

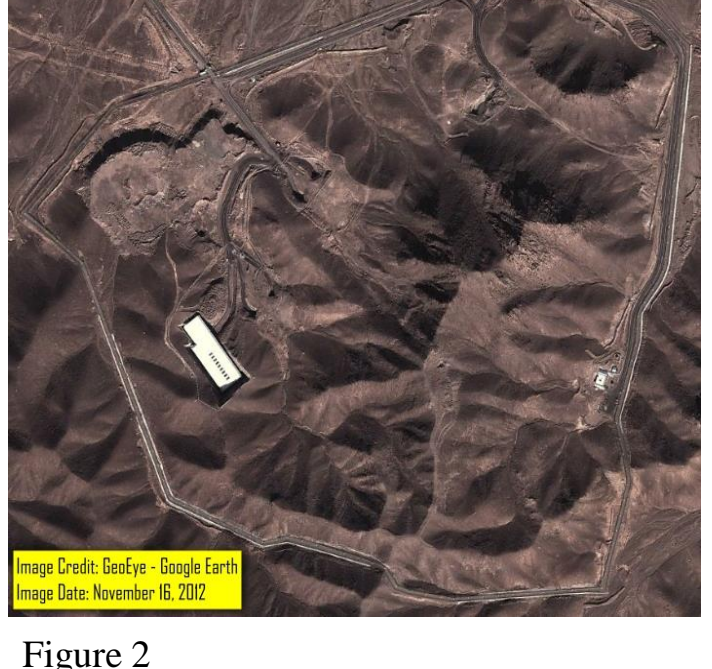

Figure 2

The Institute for Science and International Security (ISIS), a non-profit think tank based in Washington D.C., states their mission as "Working for nuclear nonproliferation and decreased weapons production." It adds, "Employing Science in the Pursuit of Peace." 18 One of their most recent reports dates from January 30, 2013. ${ }^{19}$ It recounts a possible explosion, purported by conservative news site World Net Daily to have taken place at the Fordow Fuel Enrichment Plant near the Iranian city of Qom. Accompanying this report were two satellite images (Figures 1 and 2). The photographs were arranged in an after/before sequence, and the objects under consideration were the "unidentifiable marks" annotated in Figure 1. The report speculated that these marks indicated the presence of cleanup vehicles, which would, according to ISIS, indicate the occurrence of the explosion.

Although presented through the satellite image in the guise of scientific objectivity, this ISIS report contained numerous manipulations. For instance, the images display an obviously uneven distribution of visual information - the "after-explosion" being far more crowded with annotations than the "before" image. This obvious graphic technique has the effect of bolstering the appearance of Iran's nuclear ambitions through the visual 'creation' of apparent activity irrespective of whether the "unidentifiable marks" were, in and of themselves, compelling or revealing in any way. One might also question the visual impact of the variation in filter settings used between the two images - the color contrast of "after-image" have been deliberately heightened to highlight trails and other signs of human activity more starkly. Compared to the comparatively monochromatic desert rust of the "before" image the sensation is once again one of seemingly significant activity. One final graphic manipulation evident in these images is the extension of the "after-explosion" image which extends further than the "before" so as to again highlight additional traces of building activity. (Figure 3) 


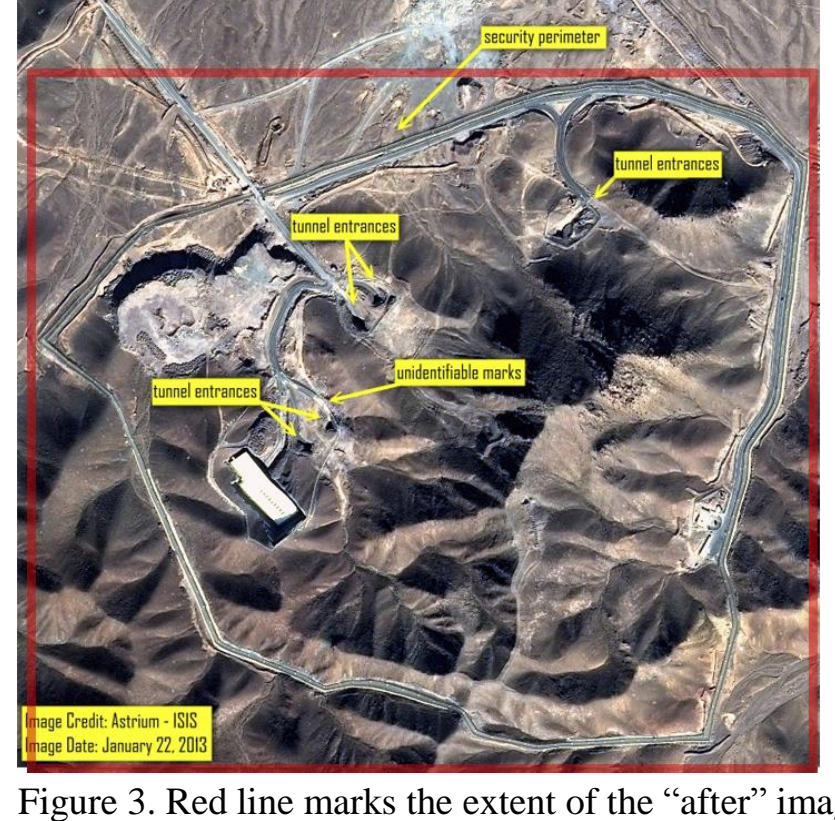

Figure 3. Red line marks the extent of the "after" image

Such striking, but obvious, visual tactics serve to increase the sense of urgency with which the US paints the need to obstruct Iran's nuclear program, which they invariably portray as a quickly developing, hostile project. ${ }^{20}$ By way of the satellite images, ISIS is allowed to operate on the convincing register of science, and to access all the attendant claims of objectivity that science affords. As defined in the ISIS mission statement: "employing science-like satellite imagery in the pursuit of international peace." The disastrous potency of such moves was clearly, and still today polemically, manifested in the exact same production of "scientifically" determined images by ISIS in the build-up to the 2003 invasion of Iraq. ${ }^{21}$ As with the previous conflict in 2003, the current nuclear standoff between the US and Iran comprises "an epistemic delirium". It is a delirium that Sam Husseini argues "must be described in terms other than those of an epistemology of science: it is the epistemology of enmity.",22

Pursuing the larger arguments that run through these questions one must ask how do the self-fulfilling epistemology at work in these satellite images of Fordow impact the city of Qom and, perhaps more interestingly, Tehran? Firstly, the claims advanced by such images crosshatch the political dimensions of the photograph physically onto the urban fabric. As a result, both cities are rendered by the direct object frame of political policy. More abstractly, the Fordow images activate the satellite's underlying crisis in the status of the human by eliminating it from the frames of reference and narrative instigated by the image. As a result, the subtext of giving a green-light to political (and possibly military) action that lies beneath the ink of sanctions to come is set: Qom, and by extension Tehran and Iran more generally, is a 'camp',vis-à-vis Agamben — a physical aporia of humans and, concomitantly, human rights.

In addition to the visual tactics deployed to support accusations of Iran's supposedly 'criminal' intent are visual strategies that reinforce the de-linking of the Iranian citizen from the state. There is the framing of the photograph such that it is filled from edge to edge with the structural details of the facility, the signs 
of the state, while the territorial boundaries of the country have been literally surpassed by an easy zoom. In addition, there is a complete lack of images that show the physical proximity of these 'signs of state' to the Iranian people themselves. One would never guess from the ISIS photographs that the Fordow Fuel Enrichment Plant is but a mere 17.8 miles from the city center of Qom - home to a population of 957,496 with upwards of 200,000 families. ${ }^{23}$ (Figure 4).

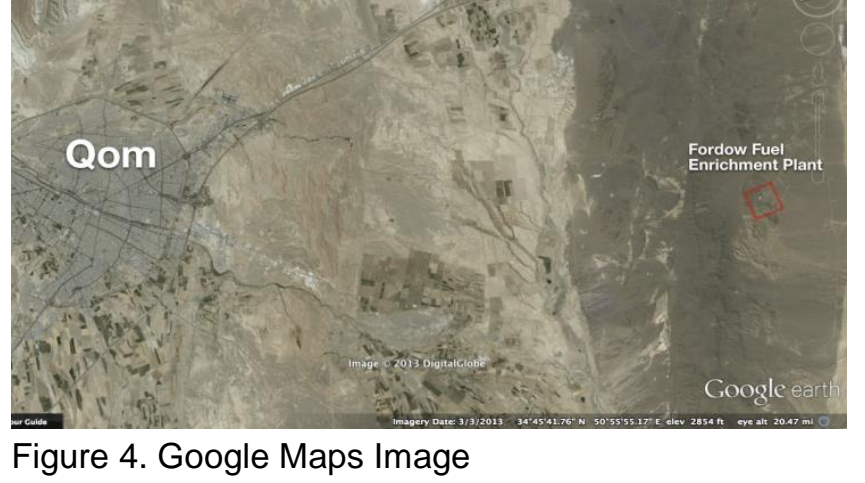

Figure 4. Google Maps Image

The politicized photograph invariably zooms in enough to nullify sovereignty, but does not zoom out enough to reveal that the de-linking of the human from the nation-state is a reductionist operation of the most politically motivated kind. These tactics offer a crucial rhetorical device that enables the US to argue that it is not targeting Iran's people, but rather Iran's nuclear plants. This not only offers weight to a purely political reading in the event of eventual military action, it allows the US to do something considerably more subtle; to transpose the Iranian citizen with the 'universal human'. This universal human is a global citizen rather than a state actor, and can thus neatly fit into (the overwhelmingly Western-oriented) universal human rights discourse, of which the US presents itself as a clear champion.

Standing in front of this rhetorical smoke screen, President Obama can make statements such as "Finally, even as we increase pressure on the Iranian government, we're sending an unmistakable message that the United States stands with the Iranian people as they seek to exercise their universal rights." ${ }^{24}$ Behind the screen however, the US is even able to slip past detailed critique from the UN Human Rights Council, whose March 2013 report on Iran reads:

"The Special Rapporteur joins the Secretary-General in continuing to express concern at the potentially negative humanitarian effect of general economic sanctions imposed on the Islamic Republic.... The Committee [on Economic, Social and Cultural Rights] noted that the inhabitant of a given country do not forfeit their basic economic, social and cultural rights by virtue of any determination that their leaders have violated norms relating to international peace and security." 25

What such comments reveal is that through a satellite image of 'elsewhere', the neat displacement of the citizen into the broadest category of being, the human, has been elicited. It is what Agamben would name the collapse of man into just man - his bare or naked life. ${ }^{26}$ The implications of this for our conceptual understanding of the city are profound. The city, a collective association of people or 'socially-inscribed 
persons', finds itself suddenly emptied - or at least emptied of people other than conceptual universal citizens. Consequently, it enters "a zone of absolute indeterminacy" in which the lives of its inhabitants do not figure. It thus precisely fulfills Agamben's terms of the 'camp'.

Once categorized in this way the potential implications for a city like Qom - located in a politically sensitive, and potentially militarily significant site - are disconcerting. For Agamben, such sites become places delimiting a space in which: "for all intents and purposes, the normal rule of law can be suspended, and in which, the fact that atrocities may or may not be committed, does not depend on the law, but rather on the civility and ethical sense of the police that act temporarily as sovereign...."27 In this case, this new subjective barometer of civility and ethics is the US which, donning the cap of international policeman, currently wields the "humanitarian" truncheon of economic sanctions. The consequences of these sanctions, for citizens of the city and the region more generally, simply do not enter into the calculation in an explicit or open way. They are however, direct and significant.

\section{SATELLITE IMAGE 2: TEHRAN SMOG}

The malleability of the satellite image is not ideologically monogamous. The Iranian state has been just as able to locate their goals, visual interventions and state interests in the space of satellite imagery with as much success as the Western media and Western states. Various satellite images over the past few years have presented the world with images of a smog-filled Tehran taken in the midst of an environmental crisis (Figure 5). The explanation of this environmental crisis through the lens of the satellite image by the Iranian state, reveals that it is no more interested than the US in mobilizing the capacities of the technological gaze to present anything approaching 'a truth'. In this case, they quite literally fail to penetrate the haziness - of both pollutants and polemics - to offer a transparency wherein the Iranian citizen can be ascertained and brought into the debate. Again, one finds that the smog not only literally obstructs the view of the Iranian people, but is discursively and visually deployed to ontologically 'invisibilize' them. Though the ambiguity of the human is cultivated for different reasons by the Iranian government than we have seen with the US, what is again demonstrated by the smog-covered image of Tehran is the satellite's mediation of the city as camp.

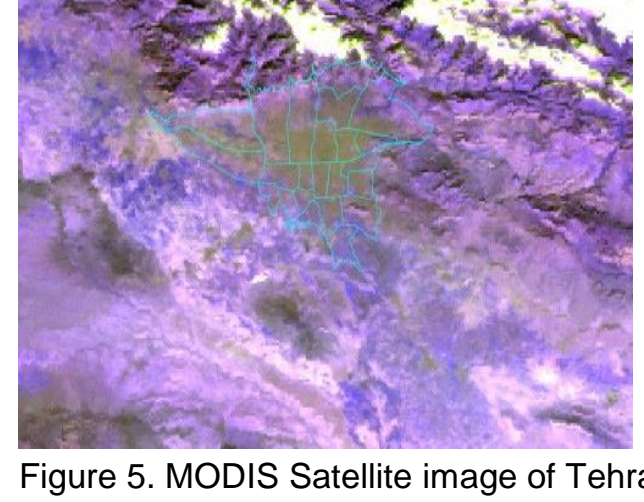

Figure 5. MODIS Satellite image of Tehran under conditions of smog (Tehran extruded in post)

This satellite image is a MODIS (Moderate Resolution Imaging Spectroradiometer) image released to the 
public in 2013. MODIS is the instrument aboard the Terra and Aqua satellites and views the entire earth's surface every one to two days. It acquires data in thirty-six spectral wavelength bands and its primary use is for environmental monitoring and studies. ${ }^{28}$ The light green area of the image highlights the aerosols over Tehran; the white areas are clouds; and the overlaid vector map indicates the locations of the city's municipal districts. ${ }^{29}$ The satellite image was central to a study entitled "Application of satellite data and GIS in studying air pollutants in Tehran", authored by Dr. Mohammad Sohrabinia from the University of Tehran; and Dr. Ali Mohammad Khorshiddoust from Tabriz University, Tabriz, Iran. The two scientists use satellite data, spatial modeling software and GIS to study the concentration of different pollutants in the air of Tehran - their stated goal being "to examine the application of satellite data and spatial analysis so as to monitor and map air pollution., 30

On the face of it, nothing could seem less suspect and the image is far more secure in its claims to scientific objectivity than those of ISIS. The coloration employed for its information visualization puts the image in the category of meteorological reports and climate change studies, while the data presented is apparently a set of purely quantitative values: chemical distributions, wavelengths and frequencies. This is not just science at work, but an exercise in the "hard" sciences. However, there is a political move located in this image - it is just not evident through visual manipulation because the political here is not local but total. The absolute 'scientization' of the smog and its presentation as the exclusive scientific object of study is the political move.

In the study by Sohrabinia and Khorshiddoust, the two scientists explain Tehran's disproportionately high levels of pollution as being "[d]ue to its geographical location, the ensnared condition as surrounded by mountain ranges, and also lack of perennial winds." This, they argue, causes "the smoke and other particulate matters produced from daily life [to] not go far in the air and thus, there is a thick layer of aerosols and other particulate matters in the nearby atmosphere." ${ }^{31}$ In the presentation of these studies, which must have been at least tacitly approved by the state, the economic sanctions banning the export of refined petroleum (as well as other goods, services and materials needed to modernize Iran's oil and natural gas sector ${ }^{32}$ ) are never cited among the causes of the smog. Indeed, when the issue has been raised, Yousef Rashidi, the director of Tehran's air quality monitoring services, has explicitly “denied the claim that low-quality gasoline is causing the problem." His official explanation is that seventy to eighty percent of the city's air pollution comes from car exhaust fumes. ${ }^{33}$

How to explain this systematic expulsion of the political from these official assessments is an interesting question. It is particularly intriguing given that it would seem to provide Iran with the perfect opportunity to criticize the United States' "diplomatic" handling of the nuclear matter, and even provoke international disapproval against the sanctions that are demonstratively not as humanitarian as the US claims. Another piece of environmental research regarding Tehran's pollution, "Mitigating Urban Heat Island Effects in Tehran Metropolitan Area", offers some insight into the government's denial of the political dimension of the issue. The study seeks to investigate the "heat-island" effect - the phenomenon whereby "heat that is absorbed during the day by buildings, roads, and other constructions in an urban area is re-emitted after sunset, resulting in areas of intense temperature differences that aggravate the formation and duration of smog ${ }^{34}$ Upon this premise, the study therefore implies that the primary pollution problem for Tehran is that there are too many buildings, too many roads, too many constructions — in short, too much of all the 


\section{Amps}

paraphernalia that constitutes a booming modern city.

Arguably, it is exactly this narrative that the Iranian government would like to put into circulation: Iran is not suffering from the pressures of economic sanctions, but rather from the pangs of wildly successful economic growth. It would thus be an argument constructed around the proposition that the country has been able to rise above the machinations of the West to stymie the Islamic Republic and that it is, in fact, prospering. According to the Foreign Affairs Review, "Car ownership became one of the government's favourite examples of rising living standards following the 1979 Iranian Revolution...."35 Therefore, explaining the environmental crisis as being above all the direct consequence of a growing number of cars accomplishes the rare feat of acknowledging a major problem while attaching a positive valence in the same breath. In the face of citizen unrest, most obviously manifested in the Green Revolution, a position suggesting government competence rather than diplomatic mishandling has obvious political benefits. It is also a reading of the situation that presents Iran as a modern industrial economy in stark contrast to the caricatures of political and economic backwardness that emanates from the political right in the West.

Moreover, through relating atmospheric degradation with development, the Iranian government cunningly circumvents the West's imposition of 'containment' by perversely aligning Tehran with a community of other countries and major cities with whom it shares the luxury afflictions of modernity. Rhetorically, it equates to an asthmatic debutante in a cigar room remarking, "we've got so much smog, we should be hosting the Olympics." Presenting this satellite image of smog in Tehran through this framework of analysis is reinforced by the image's visual evocation of countless other satellite images of pollution in various places around the world - images that have become almost universally familiar through the current global preoccupations with climate change. Indeed, a Google image search for "satellite image smog Tehran" pulls up an image of smog in China, haze over Calcutta, and an image of smog-ridden Tehran as featured on a blog called "U.S. Air Quality", concerned with pollution levels in the United States (Figures 6 and 7).
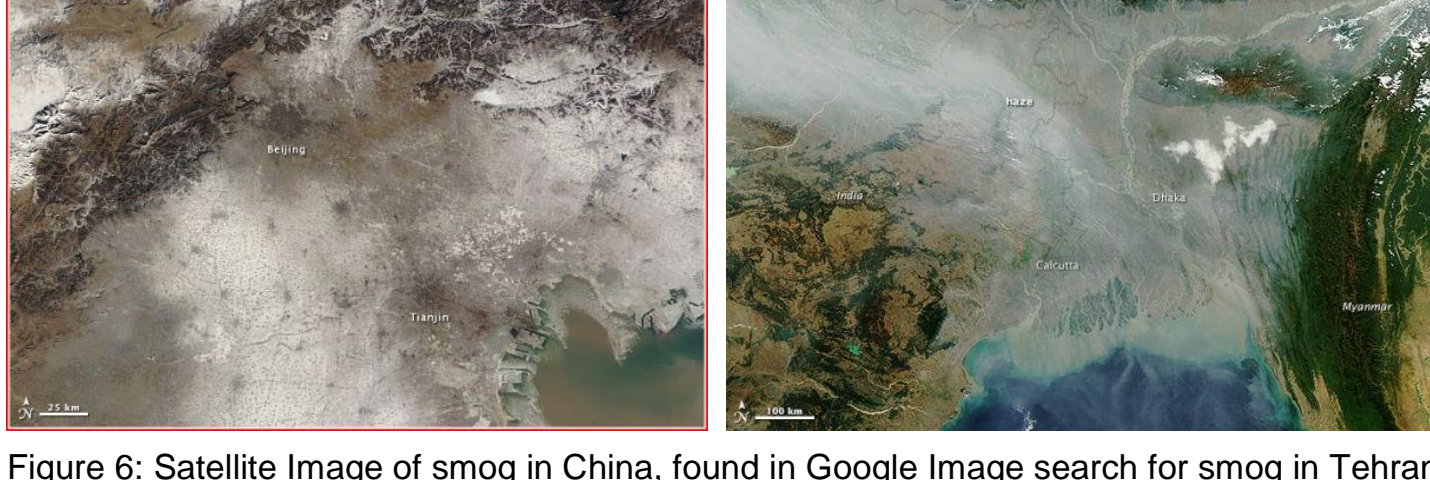

Figure 6: Satellite Image of smog in China, found in Google Image search for smog in Tehran Figure 7: Satellite Image of smog over Calcutta, found in Google Image search for smog in Tehran

In the case of satellite imagery of air pollution in Iran then, it does not become necessary to distort the image to the same levels as ISIS in order to inscribe a defined and distorting political narrative into them. It merely requires the correct political contextualization for their presentation. But amidst these clever contortions, whose arm is it really that is being twisted here? Who is being fooled and who is suffering? In 2012, air pollution is reported to have left 4,460 people dead in Tehran. ${ }^{36}$ The fact that such figures do 
not enter into the political contextualization of the images is as significant as the fact that people are not visible in them.

In this erasing of the human from both narrative and vision, these images and their use reflect that of ISIS regarding the satellite imagery of the Fordow nuclear plant. However, there is one major difference: these images of scientific studies aid and abet the official discourse surrounding the smog by visually performing the opposite of the ISIS de-linking of citizen and state. Here, citizen and state are collapsed into one through a political narrative that does the exact opposite to President Obama's statements outlined earlier. In 2006 for example, former president Hashemi Rafsanjani could comfortably make the statement that: "This [uranium enrichment] is a sensitive issue [for Iran]. We cannot give up our rights. No Iranian will be ready to give up our rights, and they [the West] should know that we will remain firm...." 37

In line with numerous politically expedient slippages regarding "rights" in the nuclear debate, the distinct identities of "we", "our", "us", "Iranian", and "Iran" remain completely hazy — or rather, hazed. Although rhetorically representing the opposite to the US stance regarding its relation to Iran and its people, in the terms of Agamben, the consequences are the same. A state of permanent crisis is imposed in which the rights and concerns of citizens are suspended and disregarded. Once again, the satellite image is central to the emergence of the city, this time Tehran, as 'camp'.

\section{CONCLUSION}

Through these images, the attempted expulsion of the designated human from politics (on the part of both sides in the Iran-US nuclear issue) meets the satellite's mediation on the stage of biopolitical control. The smog becomes a statistical regulatory device managing risk - the risk of nuclear weapons proliferation on the part of the US, and risk of citizen revolt for the Iranian government. It does so by regulating bodies as the sheer presence of empty signs or, in the terms of Agamben, by reinscribing the human as "naked life". For Iran, this reinscription comes as a part of the claim to modernity, while for the US it operates through the prism of global security and the need for an enemy. In each case, the violence of the reinscription ignores the human's traditional inscription into the nation (by the simple dint of birth) and replaces it with the notion of the human born into the boundless realm of the global or dehumanized universal - a notion facilitated here by the satellite image and its potentially destabilizing visual frame of reference.

It is as a result of this reinscription that, in both cases, the cities in question take on the qualities of Agamben's "camp", where the precariousness of "naked life" is caused by the imposition of a state of "permanent political crisis". In Amgamben's terms, not only does the state decide to "undertake the management of the biological life of the nation directly as its own task" ${ }^{38}$, but it also "no longer orders forms of life and juridical norms in a determinate space; rather, it contains within itself a dislocating localization that exceeds it, and in which virtually every form of life and every norm can be captured."39

The camp, intended as dislocating localization, is for Agamben, the hidden matrix of the politics and contradictions in which we live, and which we "must learn to recognize in all of its metamorphoses." ${ }^{40}$ In the instances outlined here, these metamorphoses occur with the aid of the satellite image and the stakes 
of apperceiving how those images partake in this mediation of the city as 'camp' are not trivial. With the abstraction of the human that comes through this mediation any number of opportunities for the construction of the 'ideal political subject' become possible. ${ }^{41}$ As seen in the case of Iranian citizens, the mad-libbed definitions ${ }^{42}$ of humanity for this 'idealized political subject' end up severely restricting the available platforms and avenues for individuals to exercise agency and to practice contestation.

In light of the potential nefarious consequences of such abstractions of the human with the aim of satellite imagery, it becomes essential to question images such as those shown here from a spatial and political standpoint that negates any sharp distinction between either perspective. When faced with these images we have to ask what it is within them that serves as a reminder of life - as a reminder of the noise that erupts when the smoothness of the hegemonic narrative of the presented image meets the complex topographies of people living out historically and culturally embedded social lives. In confronting these apparently objective spatial images we must understand and trace the mediation of the city that occurs through them; we must see them site of an aporia of human rights, and be ready to challenge the hegemonies of truth they are apt to present. As dreams for the political resolution of issues such as the Iranian nuclear question become ever more stubbornly attached to the resolution of images - the reality of information available per pixel and the abstraction of space they permit - this task becomes ever more necessary.

\footnotetext{
${ }^{1}$ Thomas Erdbrink, “Annual Buildup of Air Pollution Chokes Tehran,” New York Times, January 6, 2013. http://www.nytimes.com/2013/01/07/world/middleeast/tehran-is-choked-by-annual-buildup-of-air-pollution.html. "Alex Shams, "Seeing Through the Haze: the Politics of Reporting Sanctions and Smog in Tehran," Ajam Media Collective. January 24, 2013. http://ajammc.com/2013/01/24/seeing-through-the-haze-the-politics-of-reporting-sanctions-and-smog-in-tehran/ 3 Ibid.

4 Dwight D. Eisenhower, “Atoms for Peace” (speech, UN General Assembly, NY, December 8, 1953) Voices of Democracy: The U.S. Oratory Project. http://voicesofdemocracy.umd.edu/eisenhower-atoms-for-peace-speech-text/

5 Adam Tarock, "Iran's Nuclear Programme and the West," Third World Quarterly 27:4 (2006): 651.

6 Reza Aslan, No god but God: The Origins, Evolution, and Future of Islam. (New York: Random House, 2011), 191-193.

7 Gawdat Bahgat, "Nuclear Proliferation: The Islamic Republic of Iran,” Iranian Studies 39:3 (2006): 309.

8 Edward S. Herman and David Peterson, "The Iran 'Threat' In a Kafkaesque World,” Journal of Palestine Studies 42:1 (2012): 35.

9 "Remarks by the President Obama in Address to the United Nations General Assembly." September 21, 2011. http://www.whitehouse.gov/thepress-office/2011/09/21/remarks-president-obama-address-united-nations-general-assembly.

10 "Timeline on Iran's Nuclear Program" http://www.nytimes.com/interactive/2013/03/20/world/middleeast/Iran-nucleartimeline.html\#/\#time243_7201

${ }^{11}$ Roger Hardy. "The Iran-Iraq war: 25 years on." September 22, 2005. http://news.bbc.co.uk/2/hi/middle east/4260420.stm.

12 Adam Tarock. "Iran's Nuclear Programme and the West." Third World Quarterly 27:4 (2006), 652.

13 Ibid, 653.

$14 \mathrm{Ibid}, 650$.

${ }^{15}$ Eva Horn, "Knowing the Enemy: The Epistemology of Secret Intelligence," Grey Room 11 (Spring 2003): 58-85.

${ }^{16}$ Ibid, 78 .

${ }^{17} \mathrm{Ibid}, 66$

18 Institute for Science and International Security homepage. (Accessed July 4, 2014) http://www.isis-online.org/.

${ }^{19}$ David Albright, Robert vagyan and Andrea Stricker. http://isis-online.org/isis-reports/detail/day-after-alleged-sabotage-at-fordow-hardly-theexpected-emergency-response/8\#images.

${ }^{20}$ The brazen use of photoshop here is not without irony: the US has ridiculed Iranian government officials in the past for basic uses of photoshop in long range missile tests: "Has Iran Joined the Axis of Photoshop?" July 10, 2008.

http://www.theguardian.com/news/blog/2008/jul/10/iranianmissiletestsnotwhat.

${ }^{21}$ Sam Husseini, "David Albright Questioned on Credentials, Iran Weapons Claims, Record on Israeli Nuclear Weapons — Threatens Stakeout," The Washington Stakeout, November 15, 2011. http://www.washingtonstakeout.com/index.php/2011/11/15/david-albright/

${ }^{22}$ Ibid, 60.

23 "Qom," Encyclopaedia Britannica. (Accessed July 4, 2014) http://www.britannica.com/EBchecked/topic/485815/Qom

24 "Remarks by the President at Signing of the Iran Sanctions." July 1, 2010. http://www.whitehouse.gov/the-press-office/remarks-president$\underline{\text { signing-iran-sanctions-act }}$
} 
${ }^{25}$ Ahmed Shaheed. "Special Rapporteur's March 2013 report on the situation of human rights in the Islamic Republic of Iran." http://www.shaheedoniran.org/english/dr-shaheeds-work/latest-reports/3135-special-rapporteurs-february-2013-report-on-the-situation-ofhuman-rights-in-the-islamic-republic-of-iran.html

${ }^{26}$ Giorgio Agamben, "What is a Camp?" Means Without End: Notes on Politics. (Minneapolis: University of Minnesota Press, 2000) 41.

27 Ibid.

28 http://modis.gsfc.nasa.gov/about/

${ }^{29}$ Sohrabinia, Mohammad, and Ali Mohammad Khorshiddoust. "Application of satellite data and GIS in studying air pollutants in Tehran." Habitat International 31 (2007): 268.

${ }^{30}$ Ibid.

${ }^{31}$ Ibid.

32 "Remarks by the President at Signing of the Iran Sanctions," July 1, 2010. http://www.whitehouse.gov/the-press-office/remarks-presidentsigning-iran-sanctions-act

${ }^{33}$ Kavitha A. Davidson, “Tehran Pollution Crisis 2012: Thousands Dead In Iran's Capital As Government Warns To Stay Indoors.” January 8, 2013. http://www.huffingtonpost.com/2013/01/08/tehran-pollution-crisis-thousands-dead-iran_n_2432637.html

${ }^{34}$ Parisa Shahmonhamadi, Ulrich Cubasch, Sahar Sodoudi, and A.I. Che-Ani. "'Mitigating Urban Heat Island Effects in Tehran Metropolitan Area," Air Pollution-A Comprehensive Perspective, by Budi Haryanto. InTech (2012): 281-282.

${ }^{35}$ Alexandra Ellis, "The Anthropocene: Smog and Carcinogens - the Silent Aggressors of Iran." Foreign Affairs Review (St. Andrews) February 11, 2013. http://foreignaffairsreview.co.uk/2013/02/iran-pollution/

${ }_{36}$ Adam Clark Estes, "Life in Tehran Becomes Even More Miserable." The Atlantic Wire. January 6, 2013.

http://www.theatlanticwire.com/global/2013/01/deadly-air-pollution-crisis-life-tehran-becomes-even-more-miserable/60651/

${ }^{37}$ Adam Tarock, "Iran's Nuclear Programme and the West," Third World Quarterly 27:4 (2006): 661.

${ }^{38}$ Giorgio Agamben, "What is a Camp?" Means Without End: Notes on Politics. (Minneapolis: University of Minnesota Press, 2000$), 41$.

39 Ibid, 42.

40 Ibid, 43.

${ }^{41}$ Paradoxically this status as ideal is only assured through their (i.e. our) exclusion from politics-the practices of decision-making and the proliferation of differences.

42 Mad Libs is a phrasal template word game where one player prompts another for a list of words to substitute for blanks in a story, ex: The [adjective] day had passed quickly. For more examples: www.madlibs.com. 


\section{BIBLIOGRAPHY}

Agamben, Giorgio. "Beyond Human Rights.” Means Without End: Not on Politics. Minneapolis: University of Minnesota Press, 2000.

--. "What is a Camp?" Means Without End: Notes on Politics. Minneapolis: University of Minnesota Press, 2000.

Albright, David, Robert Avagyan and Andrea Stricker. "Day after Alleged Sabotage: Hardly the Expected Emergency Response.” http://isis-online.org/isis-reports/detail/day-after-alleged-sabotageat-fordow-hardly-the-expected-emergency-response/8\#images.

Aslan, Reza. No god but God: The Origins, Evolution, and Future of Islam. New York: Random House, 2011.

Baghat, Gawdat. "Nuclear Proliferation: The Islamic Republic of Iran,” Iranian Studies 39:3 (2006): $307-$ 327.

Davidson, Kavitha A. “Tehran Pollution Crisis 2012: Thousands Dead In Iran's Capital As Government Warns To Stay Indoors.” Jan 8, 2013. http://www.huffingtonpost.com/2013/01/08/tehranpollution-crisis-thousands-dead-iran_n_2432637.html

Eisenhower, Dwight D. “Atoms for Peace.” Speech, UN General Assembly, NY, December 8, 1953. Voices of Democracy: The U.S. Oratory Project. http://voicesofdemocracy.umd.edu/eisenhoweratoms-for-peace-speech-text/.

Ellis, Alexandra. "The Anthropocene: Smog and Carcinogens - the Silent Aggressors of Iran.” Foreign Affairs Review (St. Andrews) Feb 11, 2013. http://foreignaffairsreview.co.uk/2013/02/iranpollution/

Erdbrink, Thomas. “Annual Buildup of Air Pollution Chokes Tehran,” New York Times, January 6, 2013.

http://www.nytimes.com/2013/01/07/world/middleeast/tehran-is-choked-by-annual-buildup-ofair-pollution.html.

Estes, Adam C. "Life in Tehran Becomes Even More Miserable." The Atlantic Wire. Jan 6, 2013. http://www.theatlanticwire.com/global/2013/01/deadly-air-pollution-crisis-life-tehranbecomes-even-more-miserable/60651/

Hardy, Roger. "The Iran-Iraq war: 25 years on.” September 22, 2005.

http://news.bbc.co.uk/2/hi/middle_east/4260420.stm.

Herman, Edward S. and David Peterson, “The Iran 'Threat' In a Kafkaesque World," Journal of Palestine Studies 42:1 (2012), 24-45.

Horn, Eva. "Knowing the Enemy: The Epistemology of Secret Intelligence.” Grey Room 11 (Spring 2003), 38-55. 
Husseini, Sam. "David Albright Questioned on Credentials, Iran Weapons Claims, Record on Israeli Nuclear Weapons — Threatens Stakeout.” The Washington Stakeout, November 15, 2011.

Kurgan, Laura. Close Up at a Distance: Mapping, Technology, and Politics. Zone Books:2013.

"Remarks by the President at Signing of the Iran Sanctions," July 1, 2010. http://www.whitehouse.gov/the-press-office/remarks-president-signing-iran-sanctions-act

"Remarks by the President Obama in Address to the United Nations General Assembly." September 21, 2011. http://www.whitehouse.gov/the-press-office/2011/09/21/remarks-president-obamaaddress-united-nations-general-assembly

Shaheed, Ahmed. "Special Rapporteur's March 2013 report on the situation of human rights in the Islamic Republic of Iran." http://www.shaheedoniran.org/english/dr-shaheeds-work/latestreports/3135-special-rapporteurs-february-2013-report-on-the-situation-of-human-rightsin-the-islamic-republic-of-iran.html

Shahmonhamadi, Parisa, Ulrich Cubasch, Sahar Sodoudi, and A.I. Che-Ani. "Mitigating Urban Heat Island Effects in Tehran Metropolitan Area," Air Pollution-A Comprehensive Perspective, by Budi Haryanto. InTech (2012), 281-282.

Shams, Alex. "Seeing Through the Haze: the Politics of Reporting Sanctions and Smog in Tehran," Ajam Media Collective. Jan 24, 2013. http://ajammc.com/2013/01/24/seeing-through-the-hazethe-politics-of-reporting-sanctions-and-smog-in-tehran/

Sohrabinia, Mohammad, and Ali Mohammad Khorshiddoust. "Application of satellite data and GIS in studying air pollutants in Tehran.” Habitat International 31 (2007), 268-275.

Tarock, Adam. "Iran's Nuclear Programme and the West," Third World Quarterly 27:4 (2006), 645-664. 